\title{
OXR1 Signaling Pathway as a Possible Mechanism of Elastase-Induced Oxidative Damage in Pulmonary Cells: The Protective Role of Ellagic Acid
}

\section{Vahid Bayati}

Ahvaz Jundishapur University of Medical Sciences: Ahvaz Jondishapour University of Medical Sciences Maryam Radan ( $\sim$ radan.maryam@yahoo.com )

Ahvaz Jundishapur University of Medical Sciences: Ahvaz Jondishapour University of Medical Sciences

Mahin Dianat

Ahvaz Jundishapur University of Medical Sciences: Ahvaz Jondishapour University of Medical Sciences

Zahra Mansouri

Ahvaz Jundishapur University of Medical Sciences: Ahvaz Jondishapour University of Medical Sciences

Farzaneh Souhrabi

Ahvaz Jundishapur University of Medical Sciences: Ahvaz Jondishapour University of Medical Sciences

\section{Research Article}

Keywords: Elastase, Lung Epithelial Cell, H2O2, Oxidative Stress, OXR1, Ellagic Acid

Posted Date: February 3rd, 2022

DOI: https://doi.org/10.21203/rs.3.rs-1229337/v1

License: (c) (1) This work is licensed under a Creative Commons Attribution 4.0 International License.

Read Full License 


\section{Abstract}

Background and objective: Oxidative stress is a process that occurs through free radicals on the cell membranes which causes damage to the cell and intracellular organelles especially mitochondria membranes. $\mathrm{H} 2 \mathrm{O} 2$ induced oxidative stress in human cells is of interest in toxicological research since oxidative stress plays a main role in the etiology of several pathological conditions. Neutrophil Elastase (Serine proteinase) is involved in the pathology process of emphysema as a respiratory disease through lung inflammation, and destruction of alveolar walls. The present study investigated the direct oxidative stress effects of Elastase in comparison with $\mathrm{H} 2 \mathrm{O} 2$ on human lung epithelial cells (A549 cells) in relation to the generation of reactive oxygen species (ROS) and modulation of oxidation resistance 1 (OXR1) and its downstream pathway using the well-known antioxidant Ellagic acid as an activator of antioxidant genes.

Materials and methods: The human pulmonary epithelial cells (A549) were divided into the 9 groups including: Negative control, Positive control (H2O2), Elastase (15, 30, and $60 \mathrm{mU} / \mathrm{ml})$, Ellagic acid (10 $\mu \mathrm{mol} / \mathrm{L})$, and Elastase+Ellagic acid. Cytotoxicity, reactive oxygen spices generation, oxidative stress profile, level of reactive metabolites, and gene expression of OXR1 and its downstream genes were measured in all groups.

Results: The obtained data demonstrated that Elastase exposure caused to oxidative stress damage in a dose-depended manner which was associated with decreases in antioxidant defense system genes. Conversely, treatment with Ellagic acid as a potent antioxidant showed improved antioxidant enzyme activity and content which was in line with the upregulation of OXR1 signaling pathway genes.

Conclusions: The present findings can highlight the novel mechanism underlying the oxidative stress induces by Neutrophil Elastase through OXR1 and related genes. Moreover, the benefit of Ellagic acid on cytoprotection, resulting from its antioxidant properties was documented.

\section{Introduction}

Several cellular processes, including cell metabolism, signal transduction, and regulatory pathways, cell proliferation, and programmed cell death is affected by oxidative stress. Enhanced free radicals cause changes in the structure and function of main biological molecules in the body, such as proteins, lipids, and nucleic acids, which ultimately lead to tissue damage (1). The free radicals tend to react with other molecules due to their unbounded electrons and act as electron acceptors and oxidizing agents. The most important oxidants are reactive oxygen species (ROS), nitrogen (RNS), active species chloride, and sulfur. One of the most important oxidants that damage cells in the body are reactive oxygen species, which also plays an important role in the production of other active species, such as active nitrogen species. The endogenous sources of free radicals include mitochondria, peroxisomes, inflammatory cells, Flavin, and external sources include environmental pollution, cigarette smoke, and chemical compounds (2). The most common way to measure free radicals and oxidative stress is to determine the biomarkers 
generation from the reaction of free radicals with biological molecules in tissue, serum, and cell extract (3).

The body's cells have resistance mechanisms against oxidative stress. These systems include Catalase (CAT), Superoxide dismutase (SOD), Glutathione peroxidase (GPx), and Glutathione (GSH) (4). The eukaryotic oxidation resistance gene1 (OXR1) is a key regulatory factor that protects against free radicals (5) and was first identified during the study in the year 2000 as a gene capable of coping with oxidative stress caused by Escherichia coli (6). The OXR1 acts as an oxidative stress sensor in the cell and regulates the transcription network of genes required to detoxify oxygen free radicals and modulates the cell cycle and apoptosis process. The OXR1 factor is present in the genomes of all eukaryotes, including worms, insects, and mammals (7). However, a specific mechanism of the protective function of this gene in other oxidative stress damage is not known. The cyclin-dependent kinase inhibitor 1A (P21) and Nuclear factor (Erythroid-derived 2)-like 2 (Nrf2) proteins play an important role in controlling the level of free radicals in the body by regulating the antioxidant system (8). Under physiological conditions, factor Nrf2 is negatively regulated by Kelch-like ECH-associated protein 1 (Keap1) in low amounts in the cytoplasm. P21 activates and stabilizes the Nrf2 protein by competing with Keap1 (9). Activation of Nrf2 leads to increased expression of genes responsible for regulating the antioxidant system such as Heme oxygenase-1 (HO-1), NADH quinone oxidoreductase 1 (NQ01), and Glutamate-Cysteine Ligase (GCL) (10). Decreased Nrf2 protein is known as the first direct link between lowering the level of the antioxidant defense system and damage caused by oxidative stress in the lungs (11). On the other hand, a study has shown that OXR1 plays a key role in regulating the expression of the P21 gene as an important factor in the activation of Nrf2 protein $(5,12)$.

Natural antioxidants are the pivotal body's defense mechanism against oxidants that play an important role in maintaining redox status, eliminating reactive species, and balancing oxidation-reduction reactions in vital organs. Ellagic acid $\left(\mathrm{C}_{14} \mathrm{H}_{6} \mathrm{O}_{8}\right)$ is a natural polyphenolic compound that has a wide range of pharmaceutical and industrial applications. This molecule has shown various including anti-mutagenic, anti-oxidant, and anti-inflammatory properties (13-14). The in vitro test system of the human lung epithelial cell line (A549) is applied as a model for inducing oxidative modification using $\mathrm{H} 2 \mathrm{O} 2$ as a wellknown oxidant comparison with Elastase. The identified response to oxidative stress will be considered as a molecular damage mechanism leading to pulmonary diseases.

According to the above documents, the aim of this study was to investigate the possible changes in the oxidative stress signaling axis in pulmonary epithelial cells exposed to Elastase. Moreover, the protective role of Ellagic acid as a natural antioxidant agent in improving Elastase-induced oxidative stress will be evaluated.

\section{Material And Method}

\section{Cell treatments and preparation of cell lysates}


The Human pulmonary epithelial cell line (A549) was obtained from the Pasteur Institute of Iran (IPI). The grouping was as follows:

- Negative control group: $100 \mu \mathrm{M}$ PBS.

- Positive control group: $100 \mu \mathrm{M} \mathrm{H} 2 \mathrm{O} 2$ (well-known oxidant).

- Elastase group: $15 \mathrm{mU} / \mathrm{ml}$ for 24 hours.

- Elastase group: $30 \mathrm{mU} / \mathrm{ml}$ for 24 hours.

- Elastase group: $60 \mathrm{mU} / \mathrm{ml}$ for 24 hours (15).

- Ellagic acid group: $10 \mu \mathrm{mol} / \mathrm{L}$ for 24 hours (16).

- Elastase+Ellagic acid group: $15 \mathrm{mU} / \mathrm{ml}+$ Ellagic acid $10 \mu \mathrm{mol} / \mathrm{L}$ for 24 hours.

- Elastase+Ellagic acid group: $30 \mathrm{mU} / \mathrm{ml}+$ Ellagic acid $10 \mu \mathrm{mol} / \mathrm{L}$ for 24 hours.

- Elastase+Ellagic acid group: $60 \mathrm{mU} / \mathrm{ml}+$ Ellagic acid $10 \mu \mathrm{mol} / \mathrm{L}$ for 24 hours.

Briefly, the cells cultured and exposed to $100 \mu \mathrm{M} \mathrm{H} 2 \mathrm{O} 2$ (Sigma-Aldrich Co, USA) for $24 \mathrm{~h}$ in DMEM medium (Gibco-BRL, Germany) and at standard cultivation conditions $\left(37^{\circ} \mathrm{C}\right.$ in the presence of $\left.5 \% \mathrm{CO} 2\right)$. For the experiment groups, the A549 cells were treated with various concentration of Elastase $(15,30$, and $60 \mathrm{mU} / \mathrm{ml}$ ) with or without $10 \mu \mathrm{mol} / \mathrm{L}$ Ellagic acid (Sigma-Aldrich Co, USA) for $24 \mathrm{~h}$ to observe its effect in comparison with $\mathrm{H} 2 \mathrm{O} 2$ to induce oxidative stress which brings any change in the macromolecules. Then, the culture supernatant of all groups was collected, stored and cell lysate was prepared in order to biochemical measurements.

\section{Cytotoxicity assay}

In order to evaluate the cell viability using colorimetric MTT assay, all cell groups seeded in 24-well plates and treated with various concentrations of Elastase in FBS-free media. After overnight incubation, the MTT solution $(20 \mu \mathrm{l})$ was added and the cells were maintained for $4 \mathrm{~h}$ at $37^{\circ} \mathrm{C}$. Then, SDS $(10 \%)$ in acidified DMSO was added and the absorbance measured and the percent of cell viability in all groups were calculated in comparison to the controls.

\section{Flow-cytometric detection of reactive oxygen spices}

The A549 cells incubated with $10 \mu \mathrm{M}$ DCFH-DA as a ROS detector at $37^{\circ} \mathrm{C}$ for 30 min. subsequently, the cells were washed two times using a serum-free cell culture medium and detected via Flow cytometry.

\section{Measurement of ROS/RNS level}

The ROS levels in the supernatant fluid of A549 cells were quantified in all groups using In Vitro ROS/RNS assay Kit (Green Fluorescence; Cell Biolabs, USA). The assessments were performed three times and 


\section{Lipid peroxidation evaluation}

Lipid peroxidation as an index of oxidative stress was assessed using the Malondialdehyde (MDA) commercial Kit (Zellbio GmbH, Deutschland) according to the manufacturer's instructions.

\section{Measurement of antioxidant capacity}

The activity of SOD and GPx, and also the level of GSH and TAC was assessed using the special assay Kits (Zellbio $\mathrm{GmbH}$, Deutschland) according to the manufacturer's instructions.

\section{Determination of Protein}

Protein concentration was determined according to the Lowry method via commercial assay Kit (Bio-Rad, USA). Bovine serum albumin (BSA) was applied as the standard.

\section{Oxidative stress signaling}

The real time-PCR was used to evaluate the effects of Elastase and Ellagic acid on the expression of OXR1, P21, Nrf2, HO1, and NAD (P)H: quinone oxidoreductase-1 (NQO1) genes expression in human lung epithelial cells. The cell lysates were separated and immediately frozen in liquid nitrogen and stored at $-80^{\circ} \mathrm{C}$ until assessment. The RNA extraction in cell lysates was performed using an extraction kit (RNeasy Plus Mini Kit). The cDNA synthesis step was then performed using a kit (Quantitect Reverse Transcriptase). Finally, $1 \mu$ of cDNA and a proportional amount of each of the reciprocating primers and $10 \mu$ of a real-Time Master mix plus a proportionate volume of RNase free water in a mixture were prepared and the real-time PCR reaction was performed. Subsequently, the expression of each of the mentioned genes in comparison with Glyceride aldehyde 3-phosphate dehydrogenase (GAPDH) as the control gene was measured by Real-Time PCR. Then, the values were calculated by the comparative $\mathrm{Ct}$ (threshold cycle) method. The sequences of the forward and reverse primers of the considered genes are as follows: 
Table 1

Primer sequences for Real-Time PCR.

\begin{tabular}{|lll|}
\hline Genes & Forward & Backward \\
\hline oXR1 & TTATGGTACTGGAGAGACCTTTGTTTT & AAAACATATTATCTCCTGTCCACTTAAAGAC \\
\hline Nrf2 & GGTTTCTTCGGCTACGTTTC & CCTCCCAAACTTGCTCAATG \\
\hline P21 & TGGAGACTCTCAGGGTCGAAA & GGCGTTTGGAGTGGTAGAAATC \\
\hline H01 & ATGACACCAAGGACCAGAGC & GTGTAAGGACCCATCGGAGA \\
\hline NQ01 & ATGTATGACAAAGGACCCTTCC & TCCCTTGCAGAGAGTACATGG \\
\hline GAPDH & GCTCACTGTTCTCTCCCTC & GAGGTCAATGAAGGGGTCAT \\
\hline
\end{tabular}

\section{Statistical analysis}

Results of the current study were analyzed using the SPSS software and the normality of data was assessed using Kolmogorov-Smirnov test. All data were expressed as Mean $\pm S E M$. Differences between experimental groups were analyzed by ANOVA and followed by post hoc Tukey's test. Finally, the $p$ value

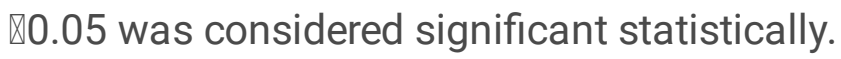

\section{Results}

\section{Cell viability measurement}

The viability of the human pulmonary epithelial cells, as evaluated by MTT assay, significantly decreased following exposure to $\mathrm{H} 2 \mathrm{O} 2$ in comparison with control cells. Exposure to Elastase for 24 hours also decreased the viability. However, statistical analysis just in the highest concentration of Elastase (60 $\mathrm{mU} / \mathrm{ml}$ ) showed significant differences in comparison with $\mathrm{H} 2 \mathrm{O} 2$ exposure cells. Once the A549 cells were treated with Ellagic acid, Elastase-induced cell toxicity was remarkably diminished. These results documented the protective properties of Ellagic acid against oxidative damage (Figure. 2).

\section{Reactive oxygen species (ROS) detection}

The DCFH-DA as a ROS detector probe was used to evaluate the influence of Elastase on cellular free radical production. As shown in Figure. 3A, the flow cytometric assessment demonstrated significant increases in the $\mathrm{H} 2 \mathrm{O} 2$ group in comparison with control cells. Exposure to Elastase showed a dosedependent enhancement in the ROS level in A549 cells compare to the $\mathrm{H} 2 \mathrm{O} 2$ which these data suggests the cytotoxic and oxidative effects of Elastase on pulmonary epithelial cells. Although the ROS production level was lower in the Ellagic acid treatment group compared to the Elastase cells.

\section{Assessment of the oxidative stress profile}


The reactive oxygen species can react with cell membrane lipids which lead to lipid peroxidation. Accordingly, MDA as a well-known biomarker of oxidative stress damage was considered in the current study. The MDA level significantly increased in the $\mathrm{H} 2 \mathrm{O} 2$ group in comparison with the control. Elastase exposure also showed enhancement in MDA level in all concentrations compare to the $\mathrm{H} 2 \mathrm{O} 2$ cells with the highest value in $60 \mathrm{mU} / \mathrm{ml}$ (Figure. 3B). On the other hand, the antioxidant profile demonstrated significant increases in response to $\mathrm{H} 2 \mathrm{O} 2$ compare with the control group. Cells incubation with Elastase for 24 hours leads to diminishing in antioxidant capacity which showed by decreases in activity of SOD (Figure. 4A), GPx (Figure. 4B), and also GSH (Figure. 4C)and TAC(Figure. 4D)levels in a dose-dependent manner. Conversely, Ellagic acid at a concentration of $10 \mu \mathrm{mol} / \mathrm{L}$ showed MDA diminishes and increases in SOD, GPx activity, and GSH, TAC levels which suggest the potent antioxidant properties of this natural antioxidant.

\section{Determination of ROS/RNS level}

To confirm the oxidative stress in exposure to Elastase, the level of reactive metabolites was determined in all cell groups. As shown in Figure. 5 a significant increase in ROS/RNS level detected in the $\mathrm{H} 2 \mathrm{O} 2$ group demonstrated the excessive oxidative stress to damage the cell components. A higher level of ROS/RNS showed in Elastase groups as well, with the highest significance in $60 \mathrm{mU} / \mathrm{ml}$ concentration. Co-treatment with Ellagic acid significantly diminished the level of ROS/RNS in dose depended manner which suggested the protective effect of Ellagic acid to relief the oxidative damage to the cells.

\section{Expression levels of antioxidant genes in A549 cells}

Following exposure to $\mathrm{H} 2 \mathrm{O} 2$ as a well-known oxidant agent the gene expression level of antioxidant key regulators including OXR1, P21, Nrf2, H01, and NQO1 significantly increased in comparison with the control group. In the Elastase exposure group, as the Elastase concentration increased the gene expression of OXR1, P21, Nrf2, HO1, and NQO1 gradually diminished in comparison with the H2O2 group. Treatment with Ellagic acid demonstrated the increases in antioxidant key regulator genes after 24 hours (Figure. 6).

\section{Discussion}

Reactive oxygen spices play a critical role in the death and survival of diseases. Previous in vivo studies have documented that excessive endogenous Elastase causes pulmonary emphysema through inflammation and oxidative stress (17-19). In this regard, current in vitro study identified the oxidative stress signaling pathway of Elastase to induce cell injuries in pulmonary epithelial cells. The results of the present study showed that Elastase decreased the gene expression of OXR1, P21, Nrf2, H01, and NQ01 in a concentration-dependent manner which was associated with decreases in antioxidant enzymes activity and content. 
Reactive oxygen spices (ROS) and other non-radical oxygen derivatives, as by-products of metabolism, are constantly generated in biological systems and cause damage to DNA, proteins, and lipids (20). The biological antioxidant defense system effectively neutralized oxidative stress by preventing free radicalsmediated organ damage (21).

OXR1 is identifying as a key regulator in resistance against the pathology of diseases which discovered first as an essential factor for inhibition of oxidative stress damage in eukaryotes organs 20 years ago (22). A study by Volkert et al. in 2000 reported that OXR1 depletion in Saccharomyces cerevisiae enhanced sensitivity to $\mathrm{H} 2 \mathrm{O} 2$ injuries (5).

Nuclear factor (erythroid-derived 2)-like 2 (Nrf2) and cyclin-dependent kinase inhibitor 1A (P21) known as crucial factors for regulating ROS levels by controlling downstream antioxidant enzymes. Indeed, subsequently to oxidative stress, Nrf2 activation leads to upregulation of several antioxidant genes, including the Heme oxygenase-1 (HO-1), and NADH quinone oxidoreductase 1 (NQO1) (23). According to a study by Yang et al. in 2014, the OXR1 gene through controlling the gene expression level of P21 (as an activator of Nrf2 protein) has a key role in the antioxidant defense system which supports the hypothesis that OXR1 protect against oxidative stress damage via P21-Nrf2-H01-NQ01 dependent manner (5). In this context, the results of the current experiment demonstrated that Elastase exposure caused to decreases in the antioxidant defense system which was showed by the lower levels of SOD, CAT, GPx activity, and GSH content. The upstream regulator's genes evaluation also revealed the downregulation of OXR1related genes which suggested the cytotoxicity effects of Elastase on lung epithelial cells through destruction of the antioxidant protection system.

Oxidative stress process seems to be involved in the pathology of emphysema process (24). As expected, in the current study the data showed a significant increase in oxidative stress biomarkers including reactive oxygen and nitrogen species (ROS/RNS) content and Malondialdehyde in response to Elastase exposure. Accordingly, it seems to antioxidant management can be considered in preventing and controlling of this destructive process. In recent years, there is a growing focus on natural antioxidants, with remarkable cytoprotective properties against cell injuries induced by oxidative stress. Ellagic acid is a polyphenolic compound found in green tea and other natural sources such as pomegranate, strawberry, raspberry, and eucalyptus bark. Ellagic acid has potent antioxidant and anti-apoptotic properties that can inhibit or prevent cellular oxidation. Ellagic acid reduces oxidative stress by scavenging free radicals and increases the antioxidant enzymes (25-27). Treatment with $10 \mu \mathrm{mol} / \mathrm{L}$ Ellagic acid for 24 hours demonstrated the inhibition effects against oxidative stress induced by Elastase which showed by increases in OXR1-P21-Nrf2-H01-NQ01 genes expression and antioxidant factors including SOD, GPx, GSH and TAC. These data suggest the potent antioxidant properties of this natural antioxidant.

In this regard, Rozentsvit et al. in the experimental study on the antioxidant effects of Ellagic acid, reported that Ellagic acid significantly diminishes free radical levels and attenuates the impairment of oxidative stress induced by high glucose medium (28). Another in vitro study by Te-Mao et al. on human bladder cancer cells showed that Ellagic acid causes to cell cycle arrest and apoptosis through P53/P21 
genes expression-depended mechanism (29). These reported data are in line with the results of the current study on the positive antioxidant properties of Ellagic acid against Elastase-induced oxidative damage.

In conclusion, the present findings can highlight the novel mechanism underlying the oxidative stress induces by Elastase through OXR1 and related genes. Moreover, the benefit of Ellagic acid on cytoprotection, resulting from its antioxidant properties was documented. However, further molecular and cellular studies on the cytoprotective activity of Ellagic acid are necessary.

\section{Declarations}

\section{Acknowledgements}

This Research study was done in the Cellular and Molecular Research Center, Basic Sciences Research Institute at Ahvaz Jundishapur University of Medical Sciences in Ahvaz, Iran. The authors gratefully acknowledge the help and financial support of the Cellular and Molecular Research Center, Ahvaz Jundishapur University of Medical Sciences [Grant No. CMRC-9813].

\section{Funding disclosures}

The authors received funding from the Cellular and Molecular Research Center, Medical Basic Sciences Research Institute, Ahvaz Jundishapur University of Medical Sciences [Grant No. APRC-9813].

\section{Authors' contributions}

All authors contributed equally to this manuscript. We further confirm that the manuscript has been read and approved by all named authors.

\section{Ethics declarations}

We confirm that any aspects of this work were approved by the Ethics Committee of Ahvaz Jundishapur University of Medical Sciences (IR.AJUMS. REC.1398.717).

\section{Competing interests}

We know of no conflicts of interest with this publication.

\section{References}

1. Schieber M, Chandel NS ROS function in redox signaling and oxidative stress.Current biology. 2014 May19;24(10):R453-62

2. Domej W, Oettl K, Renner W (2014) Oxidative stress and free radicals in COPD-implications and relevance for treatment. Int $\mathrm{J}$ Chronic Obstr Pulm Dis 9:1207 
3. Marrocco I, Altieri F, Peluso I (2017 Jan) Measurement and clinical significance of biomarkers of oxidative stress in humans. Oxidative medicine and cellular longevity. 1;2017.

4. Sharma P, Jha AB, Dubey RS, Pessarakli M (2012) Reactive oxygen species, oxidative damage, and antioxidative defense mechanism in plants under stressful conditions. Journal of botany. ;2012

5. Yang M, Luna L, Sørbø JG, Alseth I, Johansen RF, Backe PH, Danbolt NC, Eide L, Bjørås M (2014 Dec) Human OXR1 maintains mitochondrial DNA integrity and counteracts hydrogen peroxide-induced oxidative stress by regulating antioxidant pathways involving p21. Free Radic Biol Med 77(1):41-48

6. Volkert MR, Elliott NA, Housman DE (2000) Functional genomics reveals a family of eukaryotic oxidation protection genes. Proceedings of the National Academy of Sciences. Dec 19;97(26):145305

7. Oliver PL, Finelli MJ, Edwards B, Bitoun E, Butts DL, Becker EB, Cheeseman MT, Davies B, Davies KE (2011 Oct) Oxr1 is essential for protection against oxidative stress-induced neurodegeneration. PLoS Genet 20;7((10):e1002338

8. Chen W, Sun Z, Wang XJ, Jiang T, Huang Z, Fang D, Zhang DD Direct interaction between Nrf2 and p21Cip1/WAF1 upregulates the Nrf2-mediated antioxidant response.Molecular cell. 2009 Jun26;34(6):663-73

9. Bellezza I, Giambanco I, Minelli A, Donato R (2018) Nrf2-Keap1 signaling in oxidative and reductive stress. Biochimica et Biophysica Acta (BBA)-Molecular Cell Research. May 1;1865(5):721-33

10. Saha S, Buttari B, Panieri E, Profumo E, Saso L (2020 Jan) An Overview of Nrf2 Signaling Pathway and Its Role in Inflammation. Molecules 25(22):5474

11. Carlson J, Price L, Deng H Nrf2 and the Nrf2-Interacting Network in Respiratory Inflammation and Diseases. InNrf2 and its Modulation in Inflammation 2020 (pp.51-76).Springer, Cham

12. Yang $M$, Lin $X$, Rowe $A$, Rognes $T$, Eide $L$, Bjørås $M$ Transcriptome analysis of human OXR1 depleted cells reveals its role in regulating the p53 signaling pathway.Scientific reports. 2015 Nov30;5(1):1-2

13. Priyadarsini KI, Khopde SM, Kumar SS, Mohan H Free radical studies of ellagic acid, a natural phenolic antioxidant.Journal of agricultural and food chemistry. 2002 Mar27;50(7):2200-6

14. Yu M, Gouvinhas I, Rocha J, Barros Al (2021) Phytochemical and antioxidant analysis of medicinal and food plants towards bioactive food and pharmaceutical resources. Scientific reports. May 11;11(1):1-4

15. Hou HH, Cheng SL, Liu HT, Yang FZ, Wang HC, Yu CJ (2013) Elastase induced lung epithelial cell apoptosis and emphysema through placenta growth factor. Cell Death Dis 4(9):e793

16. Kim YS, Zerin T, Song HY (2013) Antioxidant action of ellagic acid ameliorates paraquat-induced A549 cytotoxicity. Biological and Pharmaceutical Bulletin 36(4):609-615

17. Pandey KC, De S, Mishra PK Role of proteases in chronic obstructive pulmonary disease.Frontiers in pharmacology. 2017 Aug8;8:512

18. Hou HH, Cheng SL, Liu HT, Yang FZ, Wang HC, Yu CJ (2013 Sep) Elastase induced lung epithelial cell apoptosis and emphysema through placenta growth factor. Cell Death Dis 4(9):e793 
19. Antunes MA, Rocco PR (2011 Dec) Elastase-induced pulmonary emphysema: insights from experimental models. Anais da Academia Brasileira de Ciencias 83(4):1385-1396

20. Park HS, Kim SR, Lee YC (2009 Jan) Impact of oxidative stress on lung diseases. Respirology 14(1):27-38

21. Biswas S, Hwang W, Kirkham JA, Rahman P (2013) I. Pharmacological and dietary antioxidant therapies for chronic obstructive pulmonary disease. Current medicinal chemistry. Jun 1;20(12):1496-530

22. Elliott NA, Volkert MR Stress induction and mitochondrial localization of Oxr1 proteins in yeast and humans. Molecular and cellular biology.2004 Apr15;24(8):3180-7

23. Tu W, Wang H, Li S, Liu Q, Sha H (2019 Jun) The anti-inflammatory and anti-oxidant mechanisms of the Keap1/Nrf2/ARE signaling pathway in chronic diseases. Aging and disease 10(3):637

24. Domej W, Oettl K, Renner W (2014) Oxidative stress and free radicals in COPD-implications and relevance for treatment. Int J Chronic Obstr Pulm Dis 9:1207

25. Ríos JL, Giner RM, Marín M, Recio MC (2018 Oct) A pharmacological update of ellagic acid. Planta Med 84(15):1068-1093

26. Ding $Y$, Zhang B, Zhou $K$, Chen $M$, Wang $M$, Jia Y, Song Y, Li Y, Wen A Dietary ellagic acid improves oxidant-induced endothelial dysfunction and atherosclerosis: role of Nrf2 activation. International journal of cardiology. 2014 Aug 20;175(3):508-14

27. Cornélio Favarin D, Martins Teixeira M, Lemos de Andrade E, de Freitas Alves C, Lazo Chica JE, Artério Sorgi C, Faccioli LH, Paula Rogerio A (2013) Anti-inflammatory effects of ellagic acid on acute lung injury induced by acid in mice. Mediators of inflammation. ;2013

28. Rozentsvit A, Vinokur K, Samuel S, Li Y, Gerdes AM, Carrillo-Sepulveda MA (2017) Ellagic acid reduces high glucose-induced vascular oxidative stress through ERK1/2/NOX4 signaling pathway. Cell Physiol Biochem 44(3):1174-1187

29. Li TM, Chen GW, Su CC, Lin JG, Yeh CC, Cheng KC, Chung JG (2005) Ellagic acid induced p53/p21 expression, G1 arrest and apoptosis in human bladder cancer T24 cells. Anticancer Research. Mar $1 ; 25(2 A): 971-9$

\section{Figures}




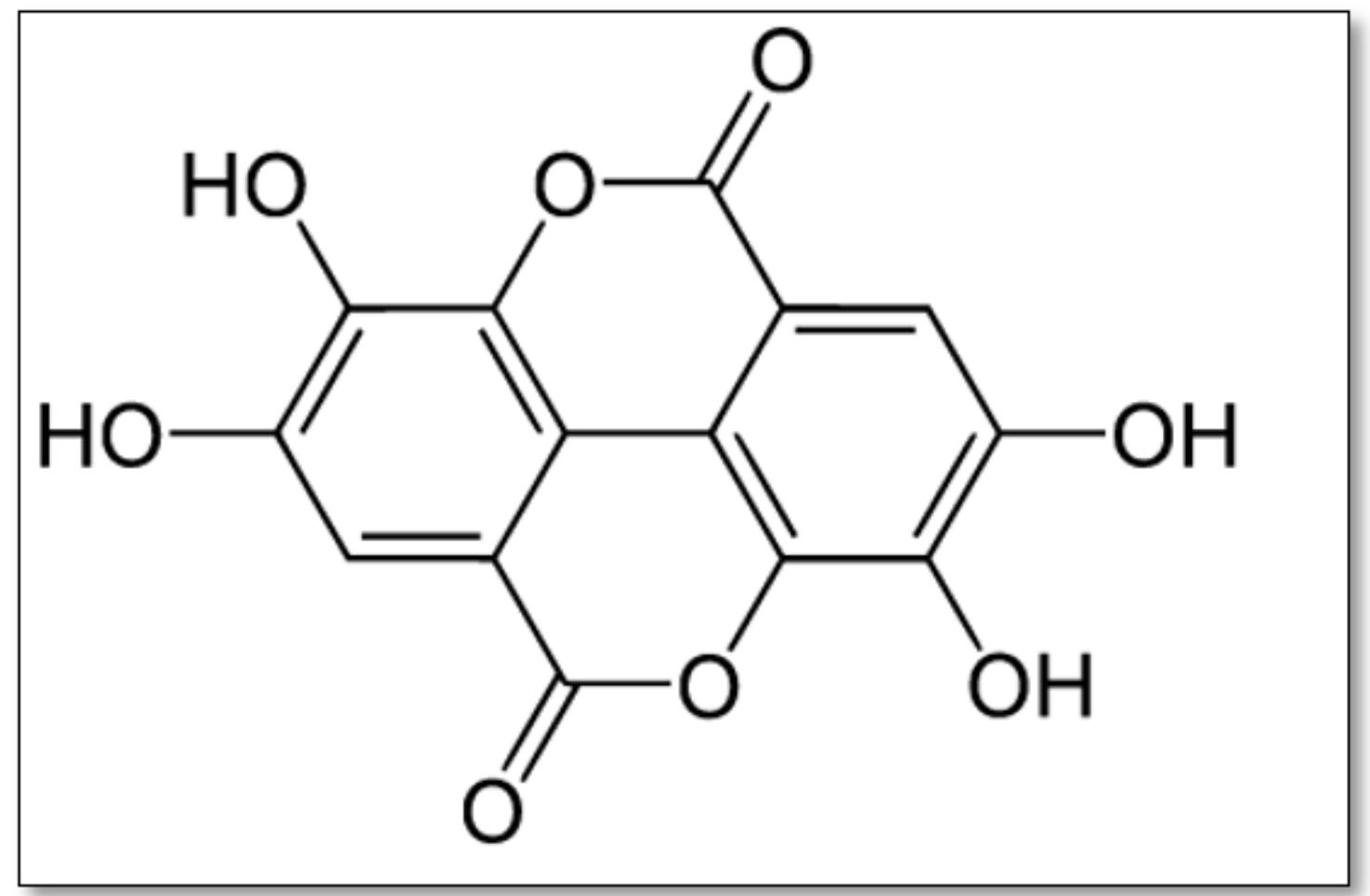

Figure 1

Chemical structure of Ellagic acid, $\mathrm{C}_{14} \mathrm{H}_{6} \mathrm{O}_{8}$. 
A
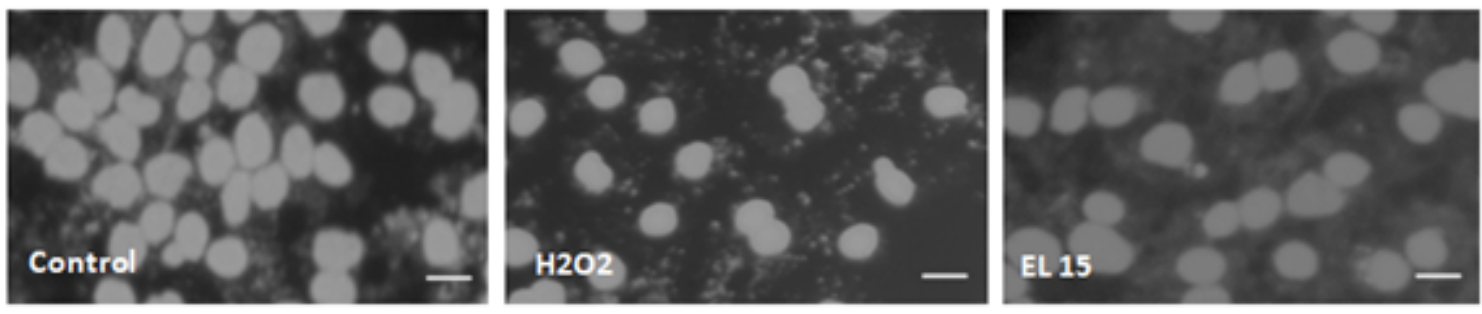

\section{Figure 2}

Cell viability assessment using Microscope images (A) and MTT assay (B) in all groups including: Negative control, Positive control (H2O2), Elastase 15 (Elastase $15 \mathrm{mU} / \mathrm{ml}$ ), Elastase 30 (Elastase 30 $\mathrm{mU} / \mathrm{ml}$ ), Elastase 60 (Elastase $60 \mathrm{mU} / \mathrm{ml}$ ), EL 15+EA (Elastase $15 \mathrm{mU} / \mathrm{ml}+$ Ellagic acid $10 \mu \mathrm{mol} / \mathrm{L}$ ), EL 30+EA (Elastase $30 \mathrm{mU} / \mathrm{ml}+E$ Ilagic acid $10 \mu \mathrm{mol} / \mathrm{L}$ ), EL 60+EA (Elastase $60 \mathrm{mU} / \mathrm{ml}+$ Ellagic acid 10 $\mu \mathrm{mol} / \mathrm{L}$ ) and EA (Ellagic acid group: $10 \mu \mathrm{mol} / \mathrm{L}$ ). Data are expressed as the mean $\pm \mathrm{SEM}$. Images were recorded at $\times 20$ magnification [scale bar $=0.1 \mathrm{~mm}$ ]. ${ }^{\star *} P<0.01$ compared with Control group, ${ }^{\#} P<0.05$ compared with $\mathrm{H} 2 \mathrm{O} 2$ group and ${ }^{\&} P<0.05$ and ${ }^{\&} \& P<0.01$ compared to Elastase group. 


\section{Figure 3}

Flow-cytometric measurement of Reactive oxygen species (ROS) (A) and Malondialdehyde (MDA) measurement (B)in all groups including:Negative control, Positive control (H2O2), Elastase 15 (Elastase $15 \mathrm{mU} / \mathrm{ml}$ ), Elastase 30 (Elastase $30 \mathrm{mU} / \mathrm{ml}$ ), Elastase 60 (Elastase $60 \mathrm{mU} / \mathrm{ml}$ ), EL 15+EA (Elastase 15 $\mathrm{mU} / \mathrm{ml}+$ Ellagic acid $10 \mu \mathrm{mol} / \mathrm{L}$ ), EL 30+EA (Elastase $30 \mathrm{mU} / \mathrm{ml}+$ Ellagic acid $10 \mu \mathrm{mol} / \mathrm{L}$ ), EL 60+EA (Elastase $60 \mathrm{mU} / \mathrm{ml}+$ Ellagic acid $10 \mu \mathrm{mol} / \mathrm{L}$ ) and EA (Ellagic acid group: $10 \mu \mathrm{mol} / \mathrm{L}$ ). Data are expressed as the mean \pm SEM. ${ }^{*} P<0.01$ compared with Control group, ${ }^{\#} P<0.05$ and ${ }^{\# \#} P<0.01$ compared with H2O2 group and ${ }^{\& \&} P<0.01$ and ${ }^{\& \& \&} P<0.001$ compared to Elastase group. 

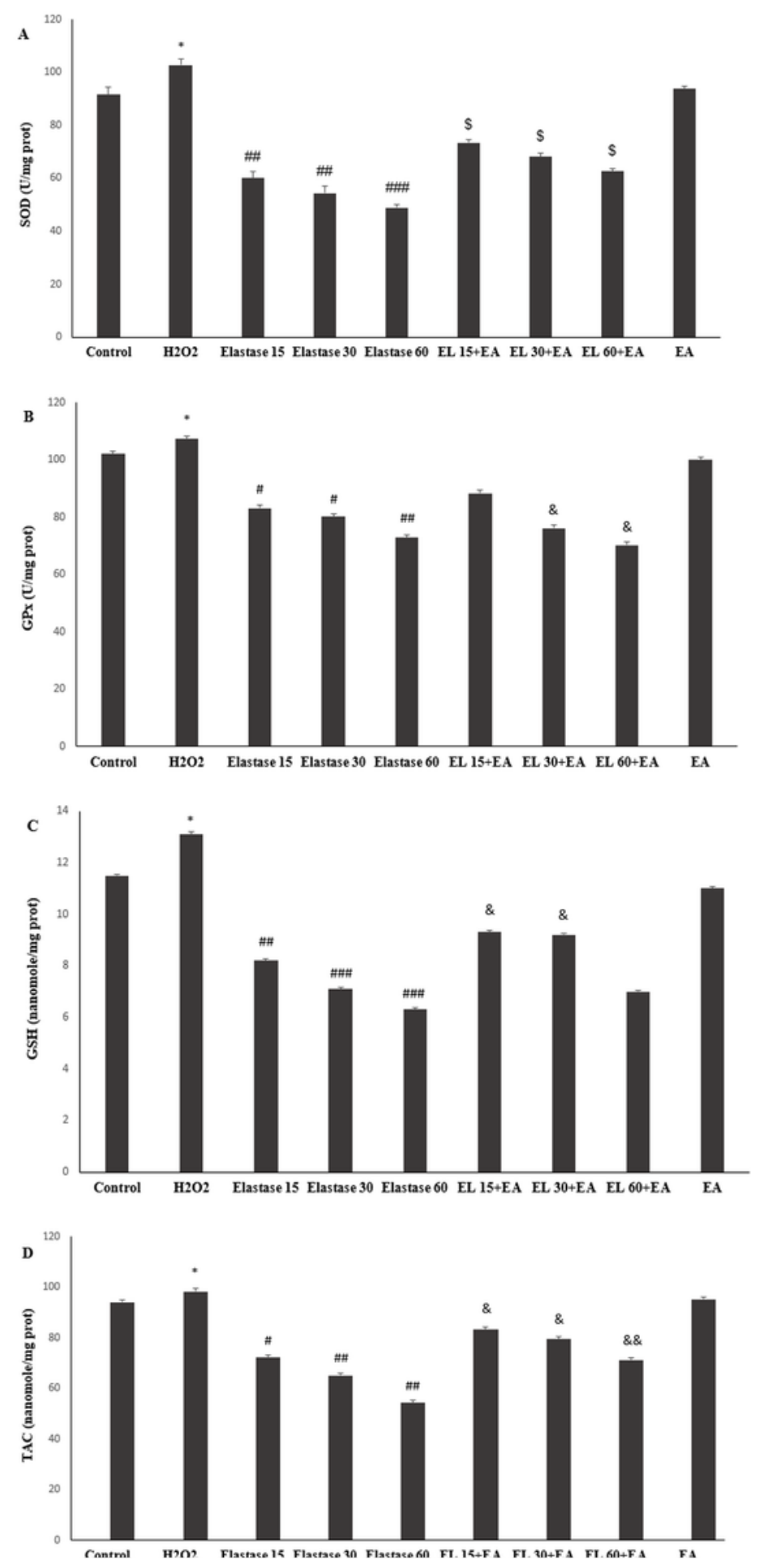

Figure 4

The activities of Superoxide dismutase (SOD) (A) andGlutathione peroxidase (GPx) (B), and Glutathione (GSH) (C) and Total antioxidant capacity (TAC) (D) concentrationin all groups including:Negative control, Positive control (H2O2), Elastase 15 (Elastase $15 \mathrm{mU} / \mathrm{ml}$ ), Elastase 30 (Elastase $30 \mathrm{mU} / \mathrm{ml}$ ), Elastase 60 (Elastase $60 \mathrm{mU} / \mathrm{ml}$ ), EL 15+EA (Elastase $15 \mathrm{mU} / \mathrm{ml}+$ Ellagic acid $10 \mu \mathrm{mol} / \mathrm{L}$ ), EL 30+EA (Elastase 30 $\mathrm{mU} / \mathrm{ml}+$ Ellagic acid $10 \mu \mathrm{mol} / \mathrm{L}$ ), EL 60+EA (Elastase $60 \mathrm{mU} / \mathrm{ml}+$ Ellagic acid $10 \mu \mathrm{mol} / \mathrm{L}$ ) and EA (Ellagic 
acid group: $10 \mu \mathrm{mol} / \mathrm{L})$. Data are expressed as the mean \pm SEM. ${ }^{*} P<0.05$ compared with Control group, ${ }^{\#} P<0.05$, ${ }^{\# \#} P<0.01$ and ${ }^{\# \# \#} P<0.001$ compared with $\mathrm{H} 202$ group and ${ }^{\&} P<0.05$ and ${ }^{\&} \& P<0.01$ compared to Elastase group.

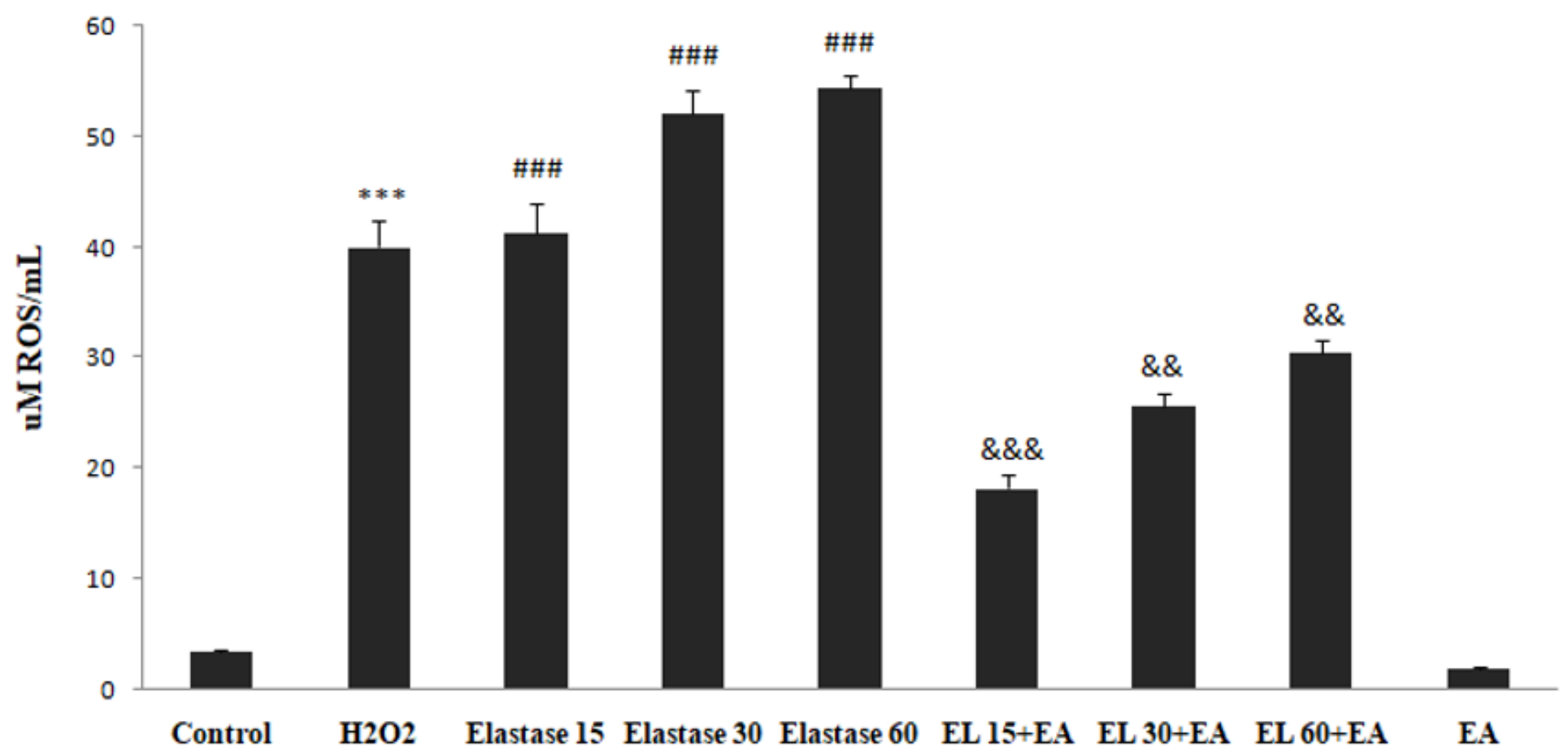

Figure 5

Levels of ROS/RNS in all groups including: Negative control, Positive control (H2O2), Elastase 15 (Elastase $15 \mathrm{mU} / \mathrm{ml}$ ), Elastase 30 (Elastase $30 \mathrm{mU} / \mathrm{ml}$ ), Elastase 60 (Elastase $60 \mathrm{mU} / \mathrm{ml}$ ), EL 15+EA (Elastase $15 \mathrm{mU} / \mathrm{ml}+$ Ellagic acid $10 \mu \mathrm{mol} / \mathrm{L}$ ), EL 30+EA (Elastase $30 \mathrm{mU} / \mathrm{ml}+$ Ellagic acid $10 \mu \mathrm{mol} / \mathrm{L}$ ), EL 60+EA (Elastase $60 \mathrm{mU} / \mathrm{ml}+$ Ellagic acid $10 \mu \mathrm{mol} / \mathrm{L}$ ) and EA (Ellagic acid group: $10 \mu \mathrm{mol} / \mathrm{L}$ ). Data are

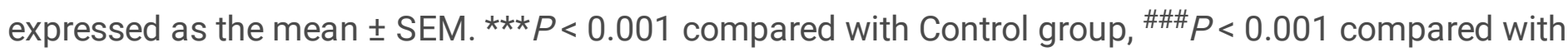
H2O2 group and ${ }^{\& \&} P<0.01$ and ${ }^{\& \& \&} P<0.001$ compared to Elastase group.

\section{Figure 6}

The gene expression levels of Oxidation Resistance 1 (OXR1), Cyclin dependent kinase inhibitor 1 (P21), Nuclear factor erythroid 2-related factor 2 (Nrf2), Heme Oxygenase 1 (H01), and NAD(P)H: quinone oxidoreductase-1 (NQ01) in all groups including:Negative control, Positive control (H2O2), Elastase 15 (Elastase $15 \mathrm{mU} / \mathrm{ml}$ ), Elastase 30 (Elastase $30 \mathrm{mU} / \mathrm{ml}$ ), Elastase 60 (Elastase $60 \mathrm{mU} / \mathrm{ml}$ ), EL 15+EA 
(Elastase $15 \mathrm{mU} / \mathrm{ml}+$ Ellagic acid $10 \mu \mathrm{mol} / \mathrm{L}$ ), EL 30+EA (Elastase $30 \mathrm{mU} / \mathrm{ml}+$ Ellagic acid $10 \mu \mathrm{mol} / \mathrm{L}$ ), EL 60+EA (Elastase $60 \mathrm{mU} / \mathrm{ml}+$ Ellagic acid $10 \mu \mathrm{mol} / \mathrm{L}$ ) and EA (Ellagic acid group: $10 \mu \mathrm{mol} / \mathrm{L}$ ). Data are expressed as the mean \pm SEM. ${ }^{*} P<0.05$ compared with Control group, ${ }^{\#} P<0.05,{ }^{\# \#} P<0.01$ and

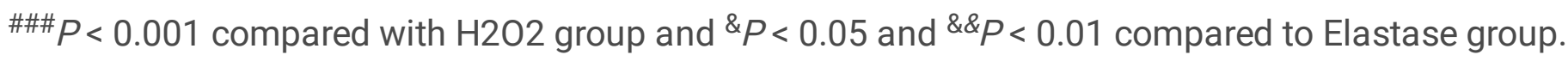

